\title{
PENANGGULANGAN KEKERASAN DI LINGKUNGAN SEKOLAH MELALUI IMPLEMENTASI PROGRAM SEKOLAH RAMAH ANAK
}

\author{
Miftahul Wahdah ${ }^{1}$, Yuniar Mujiwati ${ }^{2}$ \\ 1,2Pendidikan Pancasila dan Kewaranegaraan, STKIP PGRI Pasuruan \\ email: miftahul1097@yahoo.com \\ email: yuniar.caliptra@gmail.com
}

\begin{abstract}
This research aims to describe the prevention of violence in the environment of children through the Implementation of the Child-Friendly School Program in SMP Negeri 1 Pasuruan. The description is related to the Child-Friendly School Program as well as supporting and inhibiting factors in implementing the Child-Friendly School Program. This research uses descriptive qualitative research. The subjects of this research are the principal, teachers, students, and parents of students with the object of research including the implementation of the SRA Program at SMPN 1 Pasuruan. Data analysis techniques include data collection, data reduction, data presentation, and verification/conclusion drawing. The results of this research showed that the Child-Friendly School Program at SMPN 1 Pasuruan included (1) Communication, socialization of the Child Friendly School Program to all related parties such as teachers, students and parents; (2) human resources and infrastructure resources that support the Implementation of the Child-Friendly School Program and financial resources that draw on BOS funds; implementing the Child-Friendly School Program based on $3 P$ namely Provision, Protection, Participation. Supporting factors are human resources, infrastructure resources, and financial resources. While the inhibiting factor is the lack of environmental hygiene conditions.
\end{abstract}

Keyword: Violence, Program of Child-Friendly School

Abstrak: Penelitian ini bertujuan untuk mendeskripsikan penanggulangan kekerasan di lingkungan anak melalui Implementasi Program Sekolah Ramah Anak di SMP Negeri 1 Kota Pasuruan. Deskripsi tersebut terkait dengan Program Sekolah Ramah Anak serta faktor pendukung maupun penghambat dalam mengimplementasikan Program Sekolah Ramah Anak. Penelitian ini menggunakan jenis penelitian deskriptif kualitatif. Subjek penelitian ini yaitu kepala sekolah, guru, siswa, dan orang tua siswa dengan objek penelitian meliputi implementasi Program Sekolah Ramah Anak di SMPN 1 Pasuruan. Teknik analisis data meliputi pengumpulan data, reduksi data, penyajian data, dan verifikasi/penarikan kesimpulan. Hasil penelitian menunjukkan bahwa Program Sekolah Ramah Anak di SMPN 1 Pasuruan meliputi (1) Komunikasi, adanya sosialisasi mengenai Program Sekolah Ramah Anak kepada seluruh pihak terkait seperti guru, siswa dan orang tua; (2) Sumber daya manusia dan sumber daya sarana prasarana yang mendukung Implementasi Program Sekolah Ramah Anak dan sumber daya finansial yang mengambil dari dana BOS; menerapkan Program Sekolah Ramah Anak berdasarkan 3P yaitu Provisi, Proteksi, Partisipasi. Faktor pendukungnya adalah sumber daya manusia, sumber daya sarana prasana, dan sumber daya finansial. Sedangkan faktor penghambatnya adalah pada kondisi kebersihan lingkungan yang kurang.

Kata kunci: Kekerasan, Program, Sekolah Ramah Anak.

\section{PENDAHULUAN}

Pendidikan merupakan kebutuhan yang harus dipenuhi untuk meningkaatkan kualitas hidup. Dalam pendidikan guru memiliki peranan yang sangat penting dalam mendidik dan membentuk karakter siswa atau pola tingkah laku siswa karena 
guru merupakan penentu dan panutan bagi siswa. Sosok guru adalah orang yang identik dengan pihak yang memiliki tugas dan tanggung jawab dalam membentuk karakter atau perilaku generasi penerus bangsa. Dalam kegiatan pembelajaran hendaknya guru bisa melaksanakan pembelajaran yang menyenangkan, membimbing, mengayomi dan mendidik siswa, serta berusaha untuk tidak melakukan tindakan kekerasan secara fisik, seksual, penganiayaan emosional (bullying) atau mengabaikan anak dengan membedabedakan perlakuan antara siswa yang satu dengan yang lain.

Untuk itu pemerintah Kota Pasuruan Melalui Dinas Pendidikan Kota Pasuruan telah melakukan sosialisasi mengenai Sekolah Ramah Anak (SRA), dan telah mencoba menerapkan program Sekolah Ramah Anak (SRA) di beberapa sekolah di Kota Pasuruan salah satunya yaitu di SMPN 1 Kota Pasuruan. Program Sekolah Ramah Anak (SRA), merupakan program yang berupaya menciptakan lingkungan non kekerasan yang nyaman bagi anak di ranah pendidikan yang juga dilandasi oleh Peraturan Menteri Pemberdayaan Perempuan dan Perlindungan Anak No 8 Tahun 2014 tentang Kebijakan Sekolah Ramah Anak.

Sekolah yang mengimplemen-tasikan program ini merupakan sekolah yang berupaya menciptakan warga sekolah yang peduli terhadap lingkungan hidup, sekaligus mewujudkan sumberdaya manusia yang berkarakter dan tanggap terhadap perkembangan sosial, ekonomi, dan budaya, serta berupaya melakukan penjaminan terhadap adanya perlindungan dan pemenuhan hak-hak anak dalam semua aspek kehidupan secara terencana dan bertanggungjawab.

Sekolah dituntut untuk mampu menghadirkan dirinya sebagai sebuah lembaga, tidak sekedar tempat yang menyenangkan bagi anak untuk belajar, sekolah harus menciptakan suasana yang konduksif agar anak merasa nyaman dan dapat mengembangkan potensinya. Untuk itu sekarang di sekolah-sekolah diterapkan sekolah ramah anak agar siswa dalam belajar bisa berasa nyaman, aman, menyenangkan dan jauh dari tekanan maupun diskriminasi baik yang dilakukan oleh guru, teman sebaya, maupun oleh orang yang berada disekitarnya.

Kekerasan dalam pendidikan merupakan perilaku melampaui batas kode etik dan aturan dalam pendidikan, baik dalam bentuk fisik maupun pelecehan atas hak seseorang. Pelakunya bisa siapa saja: pimpinan sekolah, guru, staff, murid, orang tua/wali murid, atau bahkan masyarakat. Jika perilaku kekerasan melampaui batas otoritas lembaga, kode etik guru dan peraturan sekolah, maka kekerasan tersebut dapat mengarah pada pelanggaran atas HAM, dan bahkan tindak pidana. Guru yang menghukum murid sehingga mengakibatkan luka fisik atau murid yang menganiaya guru karena alasan nilai, termasuk pelanggaran HAM dan termasuk tindak pidana (Assegaf, 2004).

Faktor yang berdampak pada timbulnya kekerasan dalam dunia pendidikan ada pada kondisi internal maupun eksternal pendidikan. Dalam kondisi internal pendidikan apabila lembaga pendidikan hanya sebagai tempat belajar dan mentransfer ilmu untuk mendapatkan nilai atau lulus dalam ujian nasional, hilanglah esensi dari pendidikan itu sendiri bahwa pendidikan adalah untuk memanusiakan manusia. Tugas seorang guru bukan hanya mengajarkan mata pelajaran tetapi juga mendidik anak dan memberikan hak anak secara penuh, tetapi pada kenyataannya masih banyak guru yang memberikan hukuman fisik kepada siswa tanpa memperhatikan resiko baik fisik maupun psikis terhadap siswa. Dalam kegiatan belajar mengajar guru masih menggunakan metode pembelajaran yang konvensional. Metode pembelajaran konvensional siswa cenderung sebagai penerima informasi pasif. Siswa belajar secara individual dan kurangnya interaksi antar siswa. Guru sebagai penentu jalannya proses pembelajaran sehingga siswa tidak mempunyai kebebasan dalam mengungkapkan pendapat maupun berargumen. Metode pembelajaran konvensional sangat membatasi siswa dalam kreatifitas dan mengemukakan pendapat. Anak tidak memiliki kebebasan 
dan mendapatkan haknya secara penuh. Dalam kondisi eksternal pendidikan, kekerasan dapat ditimbulkan dari lingkungan keluarga, lingkungan sekolah, maupun lingkungan masyarakat.

Dengan demikian, Sekolah Ramah Anak harus menghormati hak siswa ketika mengekspresikan pandangannya dalam segala hal khususnya tentang ilmu pengetahuan, teknologi, seni, dan budaya, sehingga siswa merasa nyaman dan menyenangkan dalam proses belajar di sekolah. Selain itu, sekolah ramah anak harus menjamin kesempatan setiap siswa untuk menikmati haknya dalam pendidikan tanpa diskriminasi berdasarkan disabilitas, gender, suku bangsa, agama, jenis kecerdasan, dan latar belakang orang tua. Sekolah ramah anak juga harus mempertimbangkan situasi sekolah yang aman, bersih dan sehat, peduli dan berbudaya, lingkungan hidup, mampu menjamin, memenuhi, menghargai hak-hak dan perlindungan siswa dari kekerasan, diskriminasi, dan perlakuan tidak wajar lainnya, serta menjamin keikutsertaan siswa dalam perencanaan, kebijakan, pembelajaran, pengawasan, dan mekanisme pengaduan terkait pemenuhan hak dan perlindungan siswa dalam menempuh pendidikan.

Penanggulangan merupakan upaya pencegahan untuk mengatasi atau menghadapi suati kondisi atau keadaan sekaligus berupaya untuk memperbaiki yang harus dilakukan secara terus menerus dan berkesinambungan agar hal-hal yang tidak diinginkan terjadi atau terulang kembali.

Kekerasan merupakan perilaku yang tidak sah atau perlakuan yang salah. Kekerasan dapat diartikan sebagai perbuatan yang menyebabkan cedera atau matinya orang lain dan menyebabkan kerusakan fisik pada orang lain. Kekerasan yang mengakibatkan terjadinya kerusakan adalah kekerasan yang bertentangan dengan hukum (Kamus Besar Bahasa Indonesia).

Adanya beberapa tindak kekerasan dalam lembaga pendidikan yang masih merajalela merupakan indikator bahwa proses atau aktivitas pendidikan kita masih jauh dari nilai-nilai kemanusiaan. Disinilah urgensi humanisasi pendidikan. Humanisasi pendidikan merupakan upaya untuk menyiapkan generasi yang cerdas nalar, cerdas emosional, dan cerdas spiritual, bukan menciptakan manusia yang kerdil, pasif, dan tidak mampu mengatasi persoalan yang dihadapi. Sehingga untuk mengatasi masalah kekerasan tersebut terus berlanjut, maka diperlukan aksi nyata yang cepat dan tanggap dari pemerintah dan seluruh komponen masyarakat untuk menyelesaikan permasalahan ini.

Pemerintah sebagai pemegang kekuasaan tertinggi tentunya harus lebih bersikap tegas dalam menanggapi hal ini. Pemerintah harus lebih berusaha untuk melakukan perubahan, mengkonstruksi sistem pendidikan salah satunya. Kemudian, mengenai moral Tenaga pendidik. Negara perlu menyediakan pelatihan dan bimbingan pengajaran yang berperspektif setara kepada para guru $\mathrm{d}$ an calon guru sehingga dalam proses belajar mengajar tidak ada superioritas yang muncul, tidak ada lagi "guru yang selalu benar", dan tidak ada lagi pemanfaatan atas jabatan mereka untuk dengan mudah melakukan kekerasan fisik, psikis dan seksual kepada muridnya.

Aturan yang mengikat mengenai para guru pun harus diperketat, Pemerintah harus terus mengawasi jalannya pendidikan dengan terus mengontrol jalannya sistem pendidikan. Kemudian, harus ada jaminan keamanan yang pasti dalam setiap proses pembelajaran yang terjadi baik di institusi pendidikan formal maupun nonformal. Kemudian, Sanksi yang tegas mulai dari penurunan nilai akreditasi, pencopotan pimpinan sekolah, hingga pencabutan izin operasional lembaga pendidikan bila tetap membiarkan terjadinya perilaku kekerasan dan tindak amoral di sekolah.

Sosialisasi Undang-undang No. 23 tahun 2002 tentang Perlindungan Anak kepada siswa, orangtua, guru, kepala sekolah, dan birokrat pendidikan agar semua pihak tahu bagaimana melindungi anak dari berbagai bentuk kekerasan terutama dalam dunia pendidikan juga merupakan langkah dari penyelesaian masalah kekerasan ini. 
Selain itu, peran serta masyarakat juga tentu sangat dibutuhkan dalam rangka mencegah tindakan kekerasan dalam pendidikan. Mulai dari Keluarga yang merupakan lingkup terkecil dalam sebuah struktur kemasyarakatan. Keluarga harus bisa mendidik anak-anak mereka dengan kasih sayang tanpa kekerasan, karena secanggih apapun sistem pendidikan suatu negara tidak akan berhasil jika akarnya bermasalah.

Suharsimi Arikunto dan Cepi Safruddin (2014) menyatakan pengertian Program Secara umum, program dapat diartikan sebagai rencana. Sebuah program bukan hanya kegiatan tunggal yang dapat diselesaikan dalam waktu singkat, tetapi merupakan kegiatan yang berkesinambungan karena melaksanakan suatu kebijakan. Oleh karena itu, sebuah program dapat berlangsung dalam kurun waktu relatif lama. Pengertian program adalah suatu unit atau kesatuan kegiatan maka program merupakan sebuah sistem, yaitu rangkaian kegiatan yang dilakukan bukan hanya satu kali tetapi berkesinambungan. Pelaksanaan program selalu terjadi di dalam sebuah organisasi yang artinya harus melibatkan sekelompok orang.

Berdasarkan kondisi yang diuraikan di atas, maka peneliti tertarik untuk melakukan penelitian yang terkait dengan Implementasi Program Sekolah Ramah Anak di SMP Negeri 1 Kota Pasuruan. Alasan Peneliti melakukan penelitian tersebut karena Program Sekolah Ramah Anak di SMP Negeri 1 Kota Pasuruan belum pernah diteliti oleh peneliti lain pada pengimplementasian programnya.

Fokus masalah dalam penelitian ini adalah sebagai berikut: (1) Implementasi Program Sekolah Ramah Anak (SRA) di SMP Negeri 1 Kota Pasuruan untuk menanggulangi kekerasan di lingkungan sekolah. (2) Upaya Kepala Sekolah dan Guru dalam mengembangkan program SRA di SMP Negeri 1 Kota Pasuruan. (3) Faktor pendukung dan penghambat dalam mewujudkan Program Sekolah Ramah Anak (SRA) di SMP Negeri 1 Kota Pasuruan
Tujuan dalam penelitian ini adalah (1) Untuk mendeskripsikan tentang implementasi Program Sekolah Ramah Anak (SRA) untuk menanggulangi kekerasan di lingkungan sekolah. (2) Untuk mengetahui upaya Kepala Sekolah dan Guru dalam mengembangkan program SRA di SMP Negeri 1 Kota Pasuruan. (3) Untuk mengetahui faktor-faktor yang mendukung dan menghambat dalam mewujudkan Program Sekolah Ramah Anak (SRA).

\section{METODE PENELITIAN}

Penelitian ini tergolong pada tipe penelitian deskriptif dengan pendekatan kualitatif. Menurut Moleong (2011) "Penelitian kualitatif bermaksud untuk memahami fenomena tentang apa yang dialami oleh subyek penelitian misalnya, perilaku, persepsi, motivasi, tindakan dll secara holistik, dan dengan cara deskriptif dalam bentuk kata-kata dan bahasa pada suatu konteks khusus yang alamiah dan dengan memanfaatkan berbagai metode ilmiah".

Jenis penelitian ini berupaya menggambarkan kejadian atau fenomena sesuai dengan apa yang terjadi dilapangan. Penelitian ini bertujuan untuk mendeskripsikan tentang implementasi Program Sekolah Ramah Anak (SRA) untuk menanggulangi kekerasan di lingkungan sekolah, untuk mengetahui upaya Kepala Sekolah dan Guru dalam mengembangkan program SRA di SMP Negeri 1 Kota Pasuruan, untuk mengetahui faktor-faktor yang mendukung dan menghambat dalam mewujudkan Program Sekolah Ramah Anak (SRA).

Subyek yang menjadi sumber informasi bagi peneliti yaitu: (1) Kepala SMP Negeri 1 Kota Pasuruan, (2) Dewan guru SMP Negeri 1 Kota Pasuruan (3) Siswa SMP Negeri 1 Kota Pasuruan, (4) Wali murid.

Lokasi penelitian ditentukan berdasarkan pertimbangan dan tujuan penelitian. Penelitian dilakukan dalam ruang lingkup wilayah SMP Negeri 1 Kota Pasuruan. Adapun pertimbangan dalam pemilihan lokasi adalah karena SMP Negeri 
1 merupakan salah satu lembaga yang berkomitmen untuk mengimplementasikan program SRA.

Sumber data penelitian ini dibagi menjadi 2 sumber yaitu: (a) Data Primer: Menurut Moleong (2016) menyatakan "kata-kata dan tindakan orang-orang yang diamati atau diwawancarai merupakan sumber data utama". Penelitian ini dalam pemilihan informannya menggunakan teknik Snowball Sampling (sampel yang mula-mula kecil kemudian membesar). (b) Data Sekunder: Data sekunder adalah data yang didapat dari sumber bacaan dan/atau sumber lainnya yang terdiri dari surat-surat sampai dokumen dokumen resmi instansi pemerintah. Pengumpulan data sekunder dilakukan dengan menggunakan data dengan syarat data tersebut relevan. Peneliti menggunakan data sekunder untuk memperkuat penemuan dan melengkapi informasi. Sumber data sekunder dapat diperoleh dari hasil dokumentasi berupa foto, catatan dan lain sebagainya.

Pada dasarnya meneliti itu adalah ingin mendapatkan data yang valid, realibel dan objektif tentang gejala tertentu. Maka diperlukanlah teknik pengumpulan data yang tepat. Menurut (Sugiyono, 2008), "Teknik pengumpulan data merupakan langkah yang paling utama dalam penelitian,karena tujuan utama dari penelitian adalah mendapatkan data"

Untuk memperoleh data dan keterangan dalam penelitian maka penulis menggunakan teknik pengumpulan data berupa 1) observasi, 2) wawancara dan 3) dokumentasi.

Dalam penelitian kualitatif, analisis data dilakukan sejak awal penelitian dan selama proses penelitian dilaksanakan. Data diperoleh, kemudian dikumpulkan untuk diolah secara sistematis, melalui 1) pengumpulan data, 2) reduksi data, 3) 4) penyajian data dan 5) penarikan kesimpulan/Verifikasi.

\section{HASIL DAN PEMBAHASAN}

SMP Negeri 1 Kota Pasuruan merupakan salah satu sekolah negeri di Kota Pasuruan yang menerapkan program Sekolah Ramah anak. Dimana mulai melakukan penerapan sejak tahun 2017, sesuai dengan SK dari Wali Kota Pasuruan.

\section{Implementasi Program Sekolah Ramah Anak di SMP Negeri 1 Kota Pasuruan}

Program sekolah ramah anak merupakan program yang menjunjung tinggi hak anak di sekolah dengan memberikan kenyaman, keamanan dan kebebasan dalam mengungkapkan pendapat. Sekolah ramah anak menerapkan 3P yaitu Provisi, Proteksi, dan Partisipasi. Provisi yaitu memberikan apa yang dibutuhkan oleh anak. Proteksi yaitu memberikan anak perlindungan dari bahaya, ancaman dan tindak kekerasan. Sedangkan partisipasi yaitu anak diberikan kebebasan berekspresi dan mengungkapkan pendapat. Program Sekolah Ramah Anak bukan hanya memperlakukan anak secara ramah tetapi juga memberikan apa yang menjadi kebutuhan anak.

Implementasi Program Sekolah Ramah Anak yaitu bagaimana Program tersebut dikomunikasikan kepada guru, siswa maupun orang tua siswa. Kepala sekolah SMP Negeri 1 Kota Pasuruan selaku yang mengikuti training dari Program Sekolah sudah melakukan sosialisasi kepada guru, dan saat ini sedang berjalan proses pengenalan terhadap siswa. Untuk sosialisasi secara formal tentang SRA kepada siswa belum pernah diagendakan, akan tetapi proses pengenalan dilakukan di sela-sela proses KBM.

Pengarahan kepada orang tua siswa juga dilakukan oleh pihak sekolah melalui pertemuan wali murid. Hal ini bertujuan agar siswa dan orang tua siswa mengetahui dan memahami bahwa SMP Negeri 1 Kota Pasuruan menerapkan program Sekolah Ramah Anak (SRA) agar mereka bisa berperan dan mendukung kesuksesan penerapan program ini.

Dipastikan tidak ada batasan dalam hal sosialisasi antar warga sekolah sekolah. Baik itu siswa dengan guru, dengan sesama guru dan tenaga kependidikan lainnya, maupun dengan sesama siswa. Menerapkan pembiasaan slogan $5 \mathrm{~S}+$ Tomat yang terdiri dari, Senyum, Sapa, Salam, Sopan, Santun + Tolong, Maaf, Terima Kasih. Hal ini berlaku untuk semua warga sekolah. 
Tujuan menerapkan program SRA salah satunya adalah dalam untuk mencegah kekerasan di lingkungan sekolah, baik itu kekerasan secara fisik maupun kekerasan psikis.

\section{Upaya Kepala Sekolah dan Guru dalam Mengembangkan Sekolah Ramah Anak di SMP Negeri 1 Kota Pasuruan}

Upaya yang dilakukan kepala sekolah dan guru dalam mengembangkan Sekolah Ramah Anak dilakukan melalui pengembangan program-program khusus yang ada di SMP Negeri 1 Kota Pasuruan, salah satu diantaranya yaitu program jum'at bersih yang diwajibkan untuk semua siswa, dan juga ada pembiasaan sholat dhuha berjamaah setiap pagi yang sudah dijadwalkan di kelas masing-masing.

Upaya lainnya yaitu dipastikan tidak ada batasan dalam hal bersosialisasi dengan antar sekolah. Baik itu siswa dengan guru, dengan sesama guru dan tenaga kependidikan lainnya, maupun dengan sesama siswa. Menerapkan pembiasaan slogan 5S + Tomat yang terdiri dari, Senyum, Sapa, Salam, Sopan, Santun + Tolong, Maaf, Terima Kasih. Hal ini berlaku untuk semua warga sekolah.

Dalam proses KBM guru diharapkan memberikan metode pembelajaran semenarik mungkin, senyaman mungkin, dan tanpa adanya kekerasan. Baik itu kekerasan fisik maupun kekerasan psikis, contohnya saja diskriminasi terhadap kemampuan siswa. Selain itu guru juga memberikan kebebasan kepada siswa utuk mengutarakan pendapatnya, dan menganjurkan bagi siswa lain agar mendengarkan dan menghargai apa yang disampaikan oleh temannya. Untuk mengapresiasi hasil belajar baik guru bisa memberikan reward bagi siswa baik itu berupa pujian maupun nilai. Tujuannya sebagai motivasi bagi siswa.

Faktor Pendukung dan Penghambat Pelaksanaan Program Sekolah Ramah Anak di SMP Negeri 1 Kota Pasuruan

Dalam penerapan program Sekolah Ramah Anak terdapat faktor pendukung maupun faktor penghambat yang mempengarahui proses penerapan program tersebut.

Berikut yang menjadi faktor pendukung proses berjalannya implementasi program Sekolah Ramah Anak yaitu yang pertama adanya dukungan dan kerjasama dari semua guru dan semua staf. Dukungan dari siswa beserta orang tua juga menjadi pendukung keberhasilan penerapan program SRA.

Selain dukungan dan kerjasama warga sekolah berserta orang tua, faktor pendukung lainnya dapat dilihat dari kualifikasi guru atau pendidik semua memiliki gelar sarjana baik itu S1 maupun S2. Seusai pengamatan lapangan oleh peneliti terdapat 37 guru yang memiliki gelar S1 dan 7 guru yang sudah menempuh jenjang S2.

Selain dilihat dari sumber daya manusia, faktor pendukung lainnya juga dilihat dari sumber daya sarana prasarananya. Sumber daya sarana dan prasaran juga merupakan aspek penting dalam mengimplementasikan Program Sekolah Ramah Anak di SMP Negeri 1 Kota Pasuruan. Sarana dan Prasarana yang memadai menunjang dalam kegiatan belajar mengajar guru dan siswa sehingga pembelajaran dapat berlangsung secara efektif. Salah satu diantaranya adanya pemasangan LCD pada setiap kelas. LCD merupakan sarana dan prasarana yang penting dalam menunjang keefektifan dalam kegiatan belajar mengajar siswa sehingga materi yang disampaikan dalam pembelajaran dapat menarik minat siswa dalam belajar dan memberikan kenyamanan bagi siswa dalam kegiatan belajar mengajar.

Selain sumber daya manusia dan sumber daya sarana prasarana, sumber daya finansial juga sangat penting dalam menunjang penerapan Program Sekolah Ramah Anak di SMP Negeri 1 Kota Pasuruan. Sumber daya finansial dalam mengimplementasikan Program Sekolah Ramah Anak di SMP Negeri 1 Kota Pasuruan yaitu menggunakan dana Bantuan Operasional Sekolah (BOS).

Selain faktor pendukung, ada juga faktor penghambat dalam mengimplementasikan program Sekolah 
Ramah Anak. Faktor penghambat yang ada yaitu dalam hal kebersihan SMP Negeri 1 Kota Pasuruan kurang, kurangnya penghijauan seperti taman atau pohonpohon karena keterbatasan lokasi.

\section{SIMPULAN}

Implemetasi yang dilakukan pada program Sekolah Ramah Anak ini menerapkan 3P yaitu Provisi, Proteksi, dan Partisipasi. Upaya Kepala Sekolah dan Guru dalam Mengembangkan Sekolah Ramah Anak di SMP Negeri 1 Kota Pasuruan adalah melalui pengembangan program-program khusus yang ada di SMP

\section{DAFTAR RUJUKAN}

Arikunto, S. (2013). Prosedur Penelitian. Jakarta: Rineka Cipta.

Assegaf, A. R. (2004). Pendidikan Tanpa Kekerasan. Yogyakarta: Tiara Wacana Yogya.

Moleong, J. L. (2016). Metodologi Penelitian Kualitatif Edisi Revisi. Bandung: Remaja Rosdakarya.

Peraturan Menteri Pemberdayaan Perempuan dan Perlindungan Anak No 8 Tahun 2014 tentang Kebijakan Sekolah Ramah Anak.

Permatasari, D. (2017). Evaluasi Pelaksanaan Program Sekolah Ramah Anak Sebagai Upaya Pencegahan Tindak Kekerasan Terhadap Anak. Skripsi. Bandar Lampung: Universitas Lampung (online).

(http://digilib.unila.ac.id/26793/2/S

KRPSI\%20TANPA\%20BAB\%20P EMBAHASAN.pdf),

Saptarini, Y. (2015). Kekerasan dalam Lembaga Pendidikan Formal.
Negeri 1 Kota Pasuruan, salah satu diantaranya yaitu program jum'at bersih, salat dhuha berjamaah, bersosialisasi antar sekolah, serta menerapkan pembiasaan slogan 5S + Tomat. Faktor Pendukung dapat berasal dari siswa, orang tua, kualifikasi guru atau pendidik, sumber daya manusia, Sumber daya sarana, dan sumber daya finansial. Faktor penghambat dalam mengimplementasikan program Sekolah Ramah Anak dalam hal kebersihan SMP Negeri 1 Kota Pasuruan kurangnya penghijauan seperti taman atau pohonpohon karena keterbatasan lokasi.

Skripsi. Surakarta: Universitas Sebelas Maret (online). (https://digilib.uns.ac.id/dokumen/ download/14306/MjkwODM=/Kek erasan-dalam-lembaga-pendidikanformal-studi-mengenai-kekerasanoleh-guru-terhadap-siswa-sekolahdasar-di-Surakarta-abstrak.pdf)

Sugiyono. (2016). Metode Penelitian Kualitatif. Bandung: Alfabeta.

UU Nomor 20 Tahun 2003 tentang Pendidikan Nasional. Depdiknas.

UU Nomor 23 Tahun 2002 tentang Perlindungan Anak. Jakarta: Agromedia Group

Walikota Pasuruan. (2017). SK Walikota No. 188/188/423.011/2017 tentang Sekolah Ramah Anak. 
150 JURNAL PENDIDIKAN EDUTAMA, Vol.7, No.1 Januari 2020 